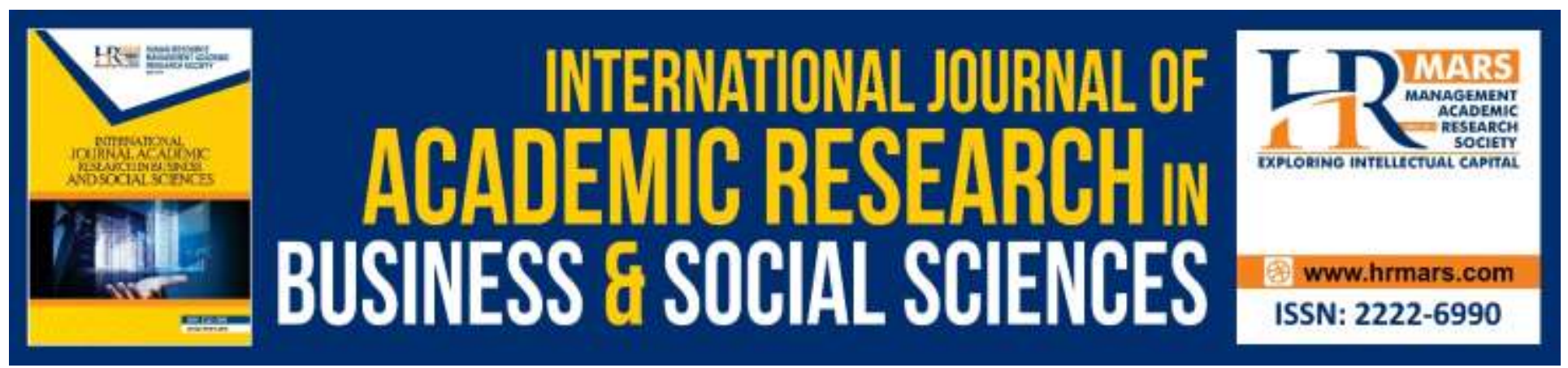

\title{
Self-Wellness Levels of Female Adolescents in Child Protection Homes
}

Wan Nursyahirah Wan Jusoh, Ku Suhaila Ku Johari \& Nur Izyan Liyana Ashiran

To Link this Article: http://dx.doi.org/10.6007/IJARBSS/v10-i6/7316

DOI:10.6007/IJARBSS/v10-i6/7316

Received: 23 April 2020, Revised: 29 May 2020, Accepted: 05 June 2020

Published Online: 25 June 2020

In-Text Citation: (Jusoh et al., 2020)

To Cite this Article: Jusoh, W. N. W., Johari, K. S. K., \& Ashiran, N. I. L. (2020). Self-Wellness Levels of Female Adolescents in Child Protection Homes. International Journal of Academic Research in Business and Social Sciences, 10(6), 476-481.

Copyright: (C) 2020 The Author(s)

Published by Human Resource Management Academic Research Society (www.hrmars.com)

This article is published under the Creative Commons Attribution (CC BY 4.0) license. Anyone may reproduce, distribute, translate and create derivative works of this article (for both commercial and non-commercial purposes), subject to full attribution to the original publication and authors. The full terms of this license may be seen

at: http://creativecommons.org/licences/by/4.0/legalcode

Vol. 10, No. 6, 2020, Pg. 476- 481

http://hrmars.com/index.php/pages/detail/IJARBSS

JOURNAL HOMEPAGE

Full Terms \& Conditions of access and use can be found at http://hrmars.com/index.php/pages/detail/publication-ethics 


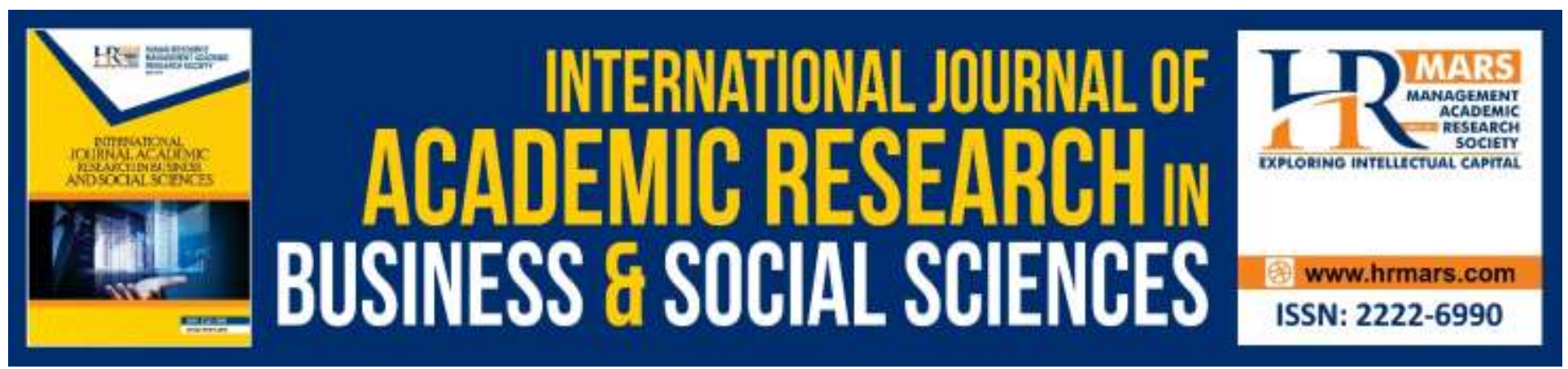

\title{
Self-Wellness Levels of Female Adolescents in Child Protection Homes
}

\author{
Wan Nursyahirah Wan Jusoh, Ku Suhaila Ku Johari \& Nur Izyan \\ Liyana Ashiran
}

Faculty of Education, Universiti Kebangsaan Malaysia, 43600 Bangi, Selangor, Malaysia.

Email: suhaila@ukm.edu.my

\begin{abstract}
Children in the care institution or welfare home are one of the groups of people dealing with highlife challenges. These children are the victim and were placed in a protection home on several factors such as abuse, neglect, persecution and is involved in court cases. Therefore, these children need to be help and cared for to ensure their wellness in a good condition. The aim of this study is to discuss children's self-wellness for five dimensions of female teen aged from 13 years to 18 years. The study participants consist of 66 girls in a child protection home under The Social Welfare Department Malaysia. A set of questionnaire consisting of 4 self-wellness inventory likert scale with high reliability values, with alpha value 0.971 was distributed to the respondents. The findings showed that overall wellness levels of the girls were at a moderate level with a mean value of 2.9060. Therefore, the children in the protection house are still require an external academic support programme and modular activities that are more systematic and objective in order to enhance their wellness
\end{abstract}

Keywords: Self-wellness, Child Protection.

\section{Introduction}

Malaysia is one of the countries that has a critical policy on children known as National Children's Policy. This policy is to safeguard the children's rights in Malaysia and one of its objectives is that each child has the right to live with care, preservation, affection, health services, support and social assistance. It is aimed safeguard the welfare of children, especially in Malaysia. In addition, the Child Welfare Committee aims to maintain the welfare and wellness of the children while the Children's Welfare Council is a non-governmental organization established with the aim to improve wellness and creating a better generation for country development. Children today are the generations that will form Malaysia in the future (Nornis et al. 2018).

Not only Malaysian children citizen and bumiputera children are given attention by the government, the refugees children are also given the appropriate rights. Like the issue faced by Karen's and Rohingya's refugee in Malaysia, refugee children were unable to go to government school as there were no specific acts in Malaysia. Therefore, the government and Non-Governmental 
Organisations (NGO) strive to provide services that can help these groups to achieve the social wellbeing needed by every individual because social well-being is a plan that has been developed in an organisation to assist individuals who need to achieve a better level of health and life. (Divaghar \& Khadijah, 2019).

Children's Wellbeing Roadmap is established as a government effort to overcome the issues of education, poverty, housing and nutrition involving the wellness of children in Malaysia in collaboration with the Ministry of Women, Family and Community Development (KPWKM), Ministry of Home Affairs (MOHA), Ministry of Education (MOE), Ministry of Health and Ministry of Rural Development (KPLB). A study by the United Nations Children's Fund (UNICEF) has found that a total of 2,142 children living in 17 locations of Projek Perumahan Rakyat (PPR) around Kuala Lumpur and Petaling Jaya were experiencing growth problems such as stunted growth and skinny. This study provides an overview that there are issues at national level on the wellness which affecting the country (Husni 2018).

Therefore, to know the wellness of children, The Five Factor Wellness Inventory (5FWEL-E) is used to obtain information (Linda et al. 2018). This inventory is an inventory consisting 94 items that include five domains: (1) Essential Self Domain includes the element of spirituality, gender identity, cultural identity, and self-care, (2) Social Self Domain includes friendship and affection, (3) Creative Self Domain includes creative thinking, emotion, self-control, positive humor, dan school task, (4) Physical Self Domain includes leisure and nutrition and (5) Coping Self Domain includes stress management, free time, realistic belief, and self-esteem. The Five Factor Wellness Inventory able to assess the well-being of an individual. The wellness gained able to prevent physical and emotional issues as well as to enhance the level of physical wellbeing and emotions (Meyer \& Sweeney, 2006). Wellness not only can give a good impact on emotions but also affect children's behaviours (Norsayyidah, 2017).

\section{Research Objectives}

The objective of the research is to:

i. Identify the reliability of self-wellness inventory tools.

ii. Study the self-wellness level of female adolescents in Children Care Home

\section{Research Methodology}

This study is a quantitative research using survey method. This study uses The Five Factor Wellness Inventory (5FWEL-E). The participants were made up of 66 girls living in Children Care Home (RKK) aged 13 to 18 years old. The research participants were asked to complete a set of questionnaires that had a section named Section A consisting of 94 items. , , , and. IS-WEL was developed by Myers \& Sweeney (2006) which consist five domains: (i) Essential Self Domain (ii) Social Self Domain (iii) Physical Self Domain (iv) Creative Self Domain (v) Coping Self Domain. Data was analyzed by using Statistical Package for the Social Sciences (SPSS) version 25. A descriptive test is used to get the mean value.

\section{Research Findings}

The reliability test for the questionnaires shows the Cronbach's alpha value is .971 as in Table 1. 
INTERNATIONAL JOURNAL OF ACADEMIC RESEARCH IN BUSINESS AND SOCIAL SCIENCES

Vol. 10, No. 6, June, 2020, E-ISSN: $2222-6990$ @ 2020 HRMARS

According to Cohen et al. (2000) Cronbach's alpha value over 0.8 showed a high level of reliability. As a result of the SPSS analysis, the mean value for a five-factor wellness test is 2.9060 as in Table 2, which is at a moderate level.

Table 1 Five Factor Wellness Inventory

Reliability

Cronbach's Alpha

Cronbach's Alpha

Based on

$\mathrm{N}$ of Item

Standardized Items

\begin{tabular}{cccc}
\hline $\begin{array}{c}\text { Five Factor } \\
\text { Wellness }\end{array}$ & .971 & .971 & 94 \\
\hline
\end{tabular}

Table 2 Five Factor Wellness Inventory

Mean Value

\begin{tabular}{lccccc}
\hline & $\mathrm{N}$ & Minimum & Maximum & Mean & $\begin{array}{c}\text { Std. } \\
\text { Deviation }\end{array}$ \\
\hline $\begin{array}{l}\text { Five Factor } \\
\text { Wellness }\end{array}$ & 66 & 1.2128 & 3.8723 & 2.9060 & 0.5225 \\
\hline
\end{tabular}

Table 3 shows the mean value of the five-domain well-being derived based on the Five-Factor Inventory of Wellness. The mean value recorded for Essential Self Domain is value (mean =3.0303), Social Self Domain with value (mean $=2.9532)$, next Creative Self Domain with value (mean $=2.8329$ ), then Physical Self Domain with value (mean $=2.8906$ ) and mean value for Coping Self Domain with value $($ mean $=2.6532)$.

Table 3 Five Factor Wellness Inventory Mean Domain Value

\begin{tabular}{cccc}
\hline & $\mathrm{N}$ & Mean & Std. Deviation \\
\hline $\begin{array}{c}\text { Essential Self } \\
\text { Domain }\end{array}$ & 66 & 3.0303 & 0.59937 \\
\hline Social Self Domain & 66 & 2.9532 & 0.64406 \\
\hline $\begin{array}{c}\text { Creative Self } \\
\text { Domain }\end{array}$ & 65 & 2.8329 & 0.52143 \\
\hline $\begin{array}{c}\text { Physical Self } \\
\text { Domain }\end{array}$ & 66 & 2.8906 & 0.61741 \\
\hline $\begin{array}{c}\text { Coping Self } \\
\text { Domain }\end{array}$ & 66 & 2.6532 & 0.53216 \\
\hline
\end{tabular}

In order to know the five-domain levels of female adolescent's self-wellness, the mean analysis is carried out by dividing the score to three levels i.e. low, medium and high. Based on the mean value obtained, the mean value range for five domain of self-wellness is between 2.10 to 3.00 as in Table 4 which is at a moderate level. From the mean value obtained Essential Self Domain record the value of (mean $=3.0303)$, Social Self Domain (mean $=2.9532)$, Creative Self Domain $($ mean $=2.8329)$, Physical Self Domain $($ mean $=2.8906)$ and Coping Self Domain (mean $=2.6532)$. 
INTERNATIONAL JOURNAL OF ACADEMIC RESEARCH IN BUSINESS AND SOCIAL SCIENCES Vol. 10, No. 6, June, 2020, E-ISSN: $2222-6990$ ๑ 2020 HRMARS

Table 4 Interpretation Score Based on Min

\begin{tabular}{cc}
\hline Mean Score & Mean Interpretation \\
\hline $1.00-2.00$ & Low \\
\hline $2.10-3.00$ & Moderate \\
\hline $3.10-4.00$ & High
\end{tabular}

\section{Discussion and Conclusion}

Research findings shows that the level of self-wellness among children at Children Care Home (RKK) is moderate with a mean value of 2.9060. Their self-wellness need to be increased in order to t support their well-being for their future life. There were five domain discussed in this study and Coping Self is the lowest score followed by Creative Self, Physical Self, Social Self and Essential Self.

Coping Self includes stress management, free time, realistic belief, and self-esteem. Lacking of coping skills among children particularly in managing stress can contribute to other mental health issues. This finding support by Moksnes \& Reidunsdatter (2019) which female adolescents tent to have more symptoms of mental health issues and self-esteem. Children and protection homes undergo life trauma and they tend to compare themselves with other children who have and stay with families.

Creative Self includes creative thinking, emotion, self-control, positive humor, dan school task. Child self-wellness can be increased when a child is able to express their emotions through certain methods such as during play (Linda et al. 2018). Children are given the opportunity to explore their own abilities through play that have been carried out in group activities The implementation of appropriate play activities or interventions like counselling intervention can enhance the selfwellness of the children in line with the study by Norsayyidatina (2017).

Physical Self includes leisure and nutrition As female adolescents, they have concern on physical appearance which can contribute to self-confidence and at the same time able to increase self-wellness. In order to have good body image, physical activities such as sport is very important. The result was in line with the study of Nornis et al. (2018) which physical activity carries a major influence that forms the wellness of children. (Rahim, Chin \& Sulaiman, 2019)

Social Self includes friendship and affection. Social Self Domain is an important dimension that can shape individuals to become a socialize person and maintain healthy relationship with others. Just like research done by Divaghar \& Khadijah (2019), the implementing agency needs to take extra caution by making initiatives that can improve the social wellness of children in order to fulfil their needs accordingly as a human being. Social development among adolescent is very important conjunction with self-maturity to become an adult. The social environment challenging to develop in this kind of setting because the lack of natural support system particularly family system.

Essential Self includes the element of spirituality, gender identity, cultural identity, and selfcare. Protection homes consider to provide supports and facilities that help the children develop their essential self. They are able to identify their gender roles that appropriate to cultural, personal selfcare and have activities related to spirituality (Rahim, Chin \& Sulaiman, 2019). Even though the element of essential self still is the highest score in this study, it is still moderate and have the need to implement more strategies related to the domain. 
In conclusion, children in the protection homes comes from various issues that are different from each other, such as child neglect and child abuse that affect themselves especially in terms of emotion. Self-wellness is important because it can enhance physical wellness as well as better emotion wellness that also affect individual behaviour. Self-wellness can also help children in the protection homes by improving the quality and satisfaction of life especially when they are in the community by knowing their needs and wishes in life. This study shows that child self-wellness of female adolescents in child protection homes can be increased through appropriate intervention by emphasizing the five domains of self-awareness. The quality of self-wellness could reduce the issue of child's problematic behaviour (Norsayyidatina, 2017). This finding can be used as a reference to a certain authority such as guidance and counseling teachers, Social Welfare Departments and the staff in protection homes staff in order to be able to perform better interventions by paying attention to the appropriate dimensions. Counselors will also be able to explore the children's self-dimensions much deeper in order to understand and help the children to grow much better.

\section{References}

Rahim, A. N. N., Chin, Y. S., Sulaiman, N. (2019). Socio-Demographic Factors and Body Image Perception Are Associated with BMI-For-Age among Children Living in Welfare Homes in Selangor, Malaysia. Nutrients, 11, 142.

Cohen, L., Manion, L., \& Morrison, K. (2000). Research Methods in Education. London: Routledge Falmer.

Cohen, L., Manion, L., Marrison, K. (2011). Research Methods in Education Edisi ke-7.New York: Routledge Taylor \& Francis Group.

Voothayakumar, D., \& Alavi, K. (2019). Meneroka Kesejahteraan Sosial Karen dan Rohingya di Sekolah Pelarian Myanmar di Chow Kit. Asian People Journal 2(1): 1-11.

Meyer, J. E., \& Sweeney, T. J. (2006). The Five Factor Wellness \& Habit Change Workbook. https://www.mindgarden.com/99-five-factor-wellness inventory [10 Januari 2020].

Jamaludin, L., Johari, Ku S. Ku., \& Amat, S. (2018). Kesan Modul Intervensi Kaunseling Berasaskan Terapi Bermain Adlerian terhadap Kesejahteraan Kanak-Kanak Mangsa Pengabaian. Jurnal Pendidikan Malaysia 43 (3):31-38.

Noor, M.H. M. (2018). 5 Kementerian Laksana Pelan Tindakan Kesejahteraan Kanak-Kanak. Berita Harian Online, 21 Jun: 1.

Moksnes, U. K., \& Reidunsdatter, R. J. (2019). Self-esteem and mental health in adolescents level and stability during a school year. Norsk Epidemiologi, 28(1-2).

Rozubi, N. C. (2017). Kesan Program Kesejahteraan Psikologi Menggunakan Kaedah Bermain Kepada Kanak-Kanak Sekolah Rendah. Tesis Dr. Fal, Fakulti Pendidikan, Universiti Malaya.

Mahali, S. N. Hj., Cosmas, G., \& Seok, C. B. (2018). Apakah yang Kita Faham Mengenai Kesejahteraan Kanak-Kanak? Kajian Kes di Pulau Gaya, Sabah. Sains Humanika 11(1): 63-71. 